\title{
OPTIMALISASI FUNGSI DAN KEDUDUKAN KAJIAN LINGKUNGAN HIDUP STRATEGIS DALAM PENYUSUNAN DAN EVALUASI RENCANA TATA RUANG DALAM SISTEM HUKUM LINGKUNGAN INDONESIA MENUJU PEMBANGUNAN BERKELANJUTAN
}

\author{
OPTIMIZATION OF FUNCTIONS AND POSITION OF \\ STRATEGIC ENVIRONMENTAL STUDY IN DEVELOPING \\ AND EVALUATION OF SPATIAL PLAN IN INDONESIA'S \\ ENVIRONMENTAL LEGAL SYSTEMS TO SUSTAINABLE \\ DEVELOPMENT
}

\author{
Maret Priyanta \\ Fakultas Hukum Universitas Padjadjaran \\ Jl. Imam Bonjol Nomor 21 Bandung 40132 \\ email : maret.priyanta@unpad.ac.id \\ Naskah diterima : 19/08/2018; direvisi : 19/12/2018; disetujui : 26/12/2018
}

\begin{abstract}
Abstrak
Kajian Lingkungan Hidup Strategis (KLHS) ditujukan untuk menjamin prinsip pembangunan berkelanjutan menjadi dasar penyusunan dan evaluasi rencana pembangunan dan rencana tata ruang (RTR). Dalam praktek, KLHS hanya ditempatkan sebagai dokumen pelengkap atau syarat formil dan terdapat ketidaksesuaian materi muatan dalam KLHS dengan kebutuhan pengaturan RTR. Pembaruan fungsi dan kedudukan KLHS dalam sistem hukum lingkungan Indonesia menjadi penting, serta mengatur secara tegas kebutuhan materi pengaturan RTR untuk mencegah dampak negatif terhadap lingkungan akibat pemanfaatan ruang. Penelitian ini menggunakan metode pendekatan yuridis normatif. Dalam hal ini digunakan metode deskriptif analitis dengan pendekatan utuh menyeluruh. Pola penelitian dan pengkajian terapan terhadap hukum, lingkungan dan tata ruang bertujuan untuk mengetahui dan memahami kebijaksanaan dalam kedudukan KLHS dalam perencanaan tata ruang. KLHS merupakan kajian ilmiah bertujuan untuk menjamin pembangunan berkelanjutan dalam setiap kegiatan pemanfaatan ruang. Pencegahan terhadap kegiatan usaha yang berdampak terhadap lingkungan tidak dapat diselesaikan oleh satu peraturan. RTR sebagai salah satu-satunya dokumen hukum rencana sekaligus instrument hukum pengendali yang menjadi dasar bagi terkait seluruh kegiatan pemanfaatan ruang harus diperkuat kedudukannya dalam sistem hukum lingkungan Indonesia, sehingga KLHS harus diperbarui fungsinya agar harmonis dan sesuai dengan kebutuhan pengaturan RTR untuk menjamin pembangunan berkelanjutan dan keadilan bagi generasi kini dan mendatang.
\end{abstract}

Kata Kunci: berkelanjutan, lingkungan, hukum, tata ruang, , pembangunan

\begin{abstract}
The Strategic Environmental Assessment (SEA) is intended to ensure the principle of sustainable development is the basis for the preparation and evaluation of development plans and spatial planning regulation In practice, SEA is only placed as a supplementary
\end{abstract}


document or formal requirement and there is a mismatch of material content in the SEA with spatial planning regulation $R T A$ regulatory requirements. Renewal of the functions and position of SEA in Indonesia's environmental legal system is important, and explicitly regulates the material requirements of spatial planning regulation arrangements to prevent negative impacts on environment due to the use of space. This study uses a normative juridical approach. In this case the analytical descriptive method is used with a holistic whole approach. The pattern of applied research and assessment of law, environment and spatial planning aims to know and understand the policies in the SEA position in spatial planning. SEA is a scientific study aimed at ensuring sustainable development in every spatial use activity. Prevention of business activities that have an impact on the environment cannot be resolved by a single regulation. Spatial planning regulation as one of the only legal documents planned as well as controlling legal instruments that form the basis for all spatial utilization activities must be strengthened in the Indonesian environmental law system, so that the SEA must be updated to be harmonious and in accordance with the requirements of spatial planning regulation to ensure sustainable development and justice for present and future generations.

\section{Keyword: sustainability, environment, law, spatial plan, development}

\section{PENDAHULUAN}

Negara pada dasarnya memiliki tanggung jawab dalam rangka melindungi segenap bangsa dan seluruh tumpah darah Indonesia. Salah satu bentuk tanggung jawab diwujudkan melalui perlindungan fungsi lingkungan untuk kepentingan generasi masa kini dan mendatang. Sejak pemberlakuan undang-undang tentang lingkungan pada tahun 1982, telah disadari bahwa pemberlakuan undang-undang terkait unsur-unsur lingkungan seperti pengaturan terkait agraria, hutan, tambang telah berkembang dan berlaku sebagai dasar kegiatan pemanfaatan lingkungan di Indonesia. Sebagai landasan pemikiran, bahwa masalah lingkungan tidak dapat diselesaikan hanya oleh undangundang, sehingga hal yang utama adalah menegaskan kedudukan sebuah undangundang dalam sistem hukum Indonesia, khususnya sistem hukum lingkungan.

Disadari bahwa undang-undang lingkungan telah mengalami 2 (dua) kali perubahan pada tahun $1997^{1}$ dan $2009^{2}$, namun ajaran hukum atau teori hukum lingkungan yang mendasarinya tetap dapat digunakan, bahkan berbagai permasalah dalam peraturan dibidang lingkungan saat ini disebabkan sudah mulai ditinggalkan dasar-dasar pemikiran hokum lingkungan pada awal pembentukannya. Hal tersebut cukup dipahami mengingat ada akhirnya sebuah undang-undang adalah produk politik sehingga berbagai kepentingan cukup mewarnai hal-hal yang disepakati untuk diatur.

Salah satu amanat mendasar dalam undang-undang lingkungan tahun 1982 adalah pernyataan secara eksplisit kedudukan undang-undang lingkungan hidup 1982 dalam sistem hukum nasional yaitu menjadi landasan untuk menilai dan menyesuaikan semua peraturan perundang-undangan yang memuat ketentuan tentang segi-segi lingkungan hidup yang telah dan akan berlaku seperti peraturan perundang-undangan mengenai Kesatu, pengairan, Kedua, pertambangan dan energi, Ketiga, kehutanan, Keempat, perlindungan dan pengawetan alam, Kelima, industri, Keenam, pemukiman, Ketujuh, tata ruang, Kedelapan,tata guna tanah, dan lainnya. Dengan pengaturan ini, semua peraturan perundang-undangan tersebut diharapkan dapat terangkum dalam satu sistem hukum lingkungan Indonesia. Bahkan berkenaan dengan pengaturan bidang tata ruang, Indonesia baru memiliki undang-undang penataan ruang pada tahun 1992, sehingga

\footnotetext{
${ }^{1}$ Undang-Undang Nomor 23 Tahun 1997 tentang Pengelolaan Lingkungan Hidup

${ }^{2}$ Undang-Undang Nomor 32 Tahun 2009 tentang Perlindungan dan Pengelolaan Lingkungan Hidup.
} 
secara tidak langsung undang-undang ini telah menyatakan pentingnya kedepan peran pengaturan tata ruang dalam perlindungan fungsi lingkungan.

Dalam perkembangannya pada tahun 1992, Undang-Undang Nomor 24 Tahun 1992 tentang penataan ruang ditetapkan, dimana pembentukan undang-undang ini berlandaskan bahwa pengelolaan sumber daya alam yang beraneka ragam di daratan, di lautan, dan di udara perlu dilakukan secara terkoordinasi dan terpadu dengan sumber daya manusia dan sumber daya buatan dalam pola pembangunan yang berkelanjutan dengan mengembangkan tata ruang dalam satu kesatuan tata lingkungan yang dinamis serta tetap memelihara kelestarian kemampuan lingkungan hidup sesuai dengan pembangunan berwawasan lingkungan, yang berlandaskan Wawasan Nusantara dan Ketahanan Nasional. Dikaji dari segi formil maupun materil, undang-undang ini dapat dianggap sebagai undang-undang yang multi/interdisipliner dari segi pengkajiandan segi pengelolaannya terpadu. ${ }^{3}$

Dalam pelaksanaannya, Selanjutnya Undang-Undang Nomor 23 Tahun 1997 tentang Pengelolaan Lingkungan Hidup, hanya sedikit mengkaitkan dengan undang-undang penataan ruang melalui Pasal 19 ayat (1) huruf a yang menyatakan bahwa dalam menerbitkan izin melakukan usaha dan/ atau kegiatan wajib diperhatikan rencana tata ruang. Kata "diperhatikan" menunjukan seberapa besar kekuatan mengikat norma dalam pasal tersebut yang belum dapat memiliki kepastian hukum manakala tidak dilaksanakan. Namun pengaturan tersebut disadari bahwa rencana tata ruang sebagai amanat undang-undang 1992 pada saat itu belum dapat secara operasional (materiil) dijadikan dasar bagi kegiatan pemanfaatan ruang.

Pada tahun 2007, pemerintah menetapkan Undang-Undang Nomor 26 Tahun 2007 tentang Penataan Ruang (UUPR), dalam undang-undang ini secara tegas menyatakan ruang merupakan wadah yang meliputi ruang darat, ruang laut, dan ruang udara, termasuk ruang di dalam bumi sebagai satu kesatuan wilayah, tempat manusia dan makhluk lain hidup, melakukan kegiatan, dan memelihara kelangsungan hidupnya. Lebih lanjut ditegaskan bahwa Penyelenggaraan penataan ruang bertujuan untuk mewujudkan ruang wilayah nasional yang aman, nyaman, produktif, dan berkelanjutan berlandaskan Wawasan Nusantara dan Ketahanan Nasional dengan Kesatu, terwujudnya keharmonisan antara lingkungan alam dan lingkungan buatan, Kedua, terwujudnya keterpaduan dalam penggunaan sumber daya alam dan sumber daya buatan dengan memperhatikan sumber daya manusia; dan Ketiga, terwujudnya pelindungan fungsi ruang dan pencegahan dampak negatif terhadap lingkungan akibat pemanfaatan ruang. ${ }^{4}$

Dengan pernyataan tersebut, secara normative undang-undang penataan ruang menempatkan kedudukannya sebagai wadah dalam rangka perlindungan fungsi lingkungan sekaligus mendorong keterpaduan antar sektor yang pada akhirnya diharapkan dapat mencegah dampak negatif terhadap lingkungan akibat pemanfaatan ruang. Berbeda dengan undang-undang penataan ruang sebelumnya, undang-undang

\footnotetext{
${ }^{3}$ Konsideran mengingat selain bersumber pada UUD 1945, Undang-Undang Nomor 24 Tahun 1992 tentang Penataan Ruang bersumber pada Undang-undang Nomor 5 Tahun 1960 tentang Peraturan Dasar Pokok-pokok Agraria; Undang-undang Nomor 5 Tahun 1974 tentang Pokok-pokok Pemerintahan Di Daerah; Undang-undang Nomor 4 Tahun 1982 tentang Ketentuan-ketentuan Pokok Pengelolaan Lingkungan Hidup; Undang-undang Nomor 20 Tahun 1982 tentang Ketentuan-ketentuan Pokok Pertahanan Keamanan Negara Republik Indonesia, sebagaimana telah 2 dari 13 diubah dengan Undang-undang Nomor 1 Tahun 1988; Peneliti berpandangan terlepas dari aspek formil dalam pengaturan Undang-Undang Nomor 12 Tahun 2011 tentang Pembentukan Peraturan Perundang-undangan, dimana sebuah undang-undang hanya perlu mencantumkan UUD 1945, namun secara materil pencantuman undang-undang terkait lainnya akan mencegah tumpang tindih peraturan dan sebagai upaya mewujudkan undang-undang yang harmonis.

${ }^{4}$ Pasal 3 Undang-Undang Nomor 26 Tahun 2007 tentang Penataan Ruang
} 
tahun 2007 ini, menguatkan kedudukan produk RTR, sebagai produk hukum yang mengikat dan lebih memberikan kepastian bagi seluruh kegiatan pemanfaatan ruang.

Dalam pengaturannya, UUPR menghasilkan produk rencana yang disebut RTR yang ditetapkan secara berjenjang dengan peraturan perundang-undangan. Rencana tata ruang menjadi dasar bagi seluruh kegiatan pemanfaatan ruang, dimana secara materil memuat, Kesatu, rencana struktur ruang wilayah, Kedua, rencana pola ruang wilayah, Ketiga, penetapan kawasan strategis, Keempat, arahan pemanfaatan ruang, Kelima,ketentuanpengendalian pemanfaatan ruang. ${ }^{5}$ Hal yang penting dari materi pengaturan rencana tata ruang adalah terdapat lampiran peta baik struktur ruang, pola ruang dan penetapan kawasan strategis yang secara teknis akan dijadikan dasar pengambilan keputusan pemerintah sesuai kewenangannya dalam pemberian izin pemanfaatan ruang, apakah sebuah kegiatan diperbolehkan untuk dilakukan.

Lebih lanjut, UUPR mengubah paradigma berkenaan dengan rencana, dimana melanggar rencana adalah melanggar hukum dan dapat dikenakan sanksi, hal tersebut secara eksplisit dinyatakan dalam Pasal 37 ayat (7) UUPR, bahwa Setiap pejabat pemerintah yang berwenang menerbitkan izin pemanfaatan ruang dilarang menerbitkan izin yang tidak sesuai dengan rencana tata ruang, serta Pasal 73 ayat (1) UUPR yang menyatakan bahwa Setiap pejabat pemerintah yang berwenang yang menerbitkan izin tidak sesuai dengan rencana tata ruang sebagaimana dimaksud dalam Pasal 37 ayat (7), dipidana dengan pidana penjara paling lama 5 (lima) tahun dan denda paling banyak Rp500.000.000,00 (lima ratus juta rupiah). Dengan ketentuan ini, secara hukum menegaskan bahwa rencana tata ruang menjadi instrument pengendali yang sangat penting, sehingga kualitas materi muatannya harus terus ditingkatkan kualitasnya untuk menjamin kesejahteraan bagi manusia dan makhluk hidup lainnya.

Pada tahun 2009, UUPPLH ditetapkan menggantikan undang-undang lingkungan tahun 1997, salah satu ketentuan yang penting dalam kaitannya dengan rencana tata ruangyaitu ketentuan dalam Pasal 15 ayat (2) huruf a, dinyatakan bahwa pemerintah pusat dan pemerintah daerah wajib melaksanakan KLHS ke dalam penyusunan atau evaluasi rencana tata ruang wilayah beserta rencana rincinya, rencana pembangunan jangka panjang (RPJP), dan rencana pembangunan jangka menengah (RPJM) nasional, provinsi, dan kabupaten/kota. ${ }^{6}$ KLHS pada dasarnya merupakan Kajian lingkungan hidup strategis, adalah rangkaian analisis yang sistematis, menyeluruh, dan partisipatif untuk memastikan bahwa prinsip pembangunan berkelanjutan telah menjadi dasar dan terintegrasi dalam pembangunan suatu wilayah dan/atau kebijakan, rencana, dan/ atau program. Norma yang tegas menyatakan KLHS merupakan instrument wajib, berimplikasi bahwa KLHS memegang peranan penting terhadap kualitas rencana tata ruang di Indonesia pasca ditetapnya UUPPLH.

Dalam rangka menjalankan amanat KLHS, Pasal 19 UUPPLH menyatakan bahwa untuk menjaga kelestarian fungsi lingkungan hidup dan keselamatan masyarakat, setiap perencanaan tata ruang wilayah wajib didasarkan pada KLHS dan Perencanaan tata ruang wilayah ditetapkan dengan memperhatikan daya dukung dan daya tampung lingkungan hidup. Hal ini menunjukan fungsi KLHS yang sangat berpengaruh pada materi muatan rencana tata ruang. Berdasarkan Peraturan Menteri Negara Lingkungan Hidup Republik Indonesia Nomor 09 Tahun 2011 Tentang Pedoman Umum Kajian

\footnotetext{
${ }^{5}$ Lihat Peraturan Menteri Pekerjaan Umum Nomor : 16/PRT/M/2009 Tentang Pedoman Penyusunan Rencana Tata Ruang Wilayah Kabupaten

${ }^{6}$ Lihat Maret Priyanta, Desember 2015, Pembaruan dan Harmonisasi Peraturan Perundang-undangan Bidang Lingkungan dan Penataan Ruang Menuju Pembangunan Berkelanjutan, Hassanudin Law review (HARLEV), Volume I Issue 3hlm.347.
} 
Lingkungan Hidup Strategis, beberapa ilustrasi intergrasi KLHS dalam rencana tata ruang masih bersifat umum serta tidak tegas. Pada prinsipnya KLHS menjadi tanggung jawab pemerintah, pusat, provinsi dan kabupaten/kota sesuai dengan kewenangannya. Dengan keterkaitan KLHS dengan rencana pembangunan dan RTR menimbulkan ketidakpastian apakah terdapat 1 (satu) dokumen KLHS yang isinya mencakup materi kajian/ integrasi pada rencana pembangunan dan rencana tata ruang, atau terdapat KLHS yang khusus memenuhi kebutuhan penyusunan dan evaluasi rencana tata ruang, mengingat KLHS juga berfungsi menjadi dasar untuk proses Analisis Mengenai Dampak Lingkungan.

Dalam praktek, KLHS menjadi barometer khususnya bagi DPRD dan LSM di daerah untuk menilai kelayakan dalam proses penyusunan dan evaluasi RTRW, banyak rancangan peraturan daerah tentang RTRW yang terhambat dimana dalam proses ternyata belum memiliki dokumen KLHS bahkan segera untuk dibuat ${ }^{7}$ untuk kepentingan penyusunan rencana tata ruang. Hal tersebut menunjukan belum dianggap pentingnya dokumen KLHS dalam proses penyusunan rencana tata ruang saat ini. Pada tahun 2017, kementerian Lingkungan Hidup dan Kehutanan memerintahkan KLHS masuk dalam peraturan daerah tentang reklamasi yang pada prinsipnya merupakan peraturan daerah tentang rencana tata ruang. ${ }^{8}$

Berkenaan dengan KLHS terkait dengan rencana tata ruang Pemerintah melalui Direktorat Jenderal Penataan Ruang Kementerian Pekerjaan Umum ${ }^{9}$ pada tahun 2014 telah mengupayan menyusun pedoman KLHS bidang penataan ruang, namun terkendala dengan kewenangan dan materi muatan yang sesuai dengan Peraturan Menteri Negara Lingkungan Hidup Republik Indonesia Nomor 09 Tahun 2011 Tentang Pedoman Umum Kajian Lingkungan Hidup Strategis, sehingga hal ini menimbulkan ketidakpastian dalam penyusunan rencana tata ruang yang akan berdampak pada kualitas sebuah rencana tata ruang yang ditetapkan. ${ }^{10}$

KLHS sebagai sebuah kajian pada dasarnya merupakan instrument penting dalam perlindungan dan pengelolaan lingkungan, sehingga integrasi yang jelas berkenaan dengan fungsi dan keterkaitannya khususnya dengan rencana tata ruang menjadi penting dengan memperhatikan kebutuhan pengaturan rencana tata ruang. Hal ini harus disadari bahwa dalam rangka mewujudkan pembangunan berkelanjutan di Indonesia, tidak dapat selesai dengan 1 (satu) undang-undang, namun masing-masing undang-undang terkait lingkungan harus menegaskan kedudukannya dalam sistem hukum lingkungan nasional.

Berdasarkan latar belakang yang diuraikan, permasalahan yang akan dikaji antara lain bagaimana fungsi dan kedudukan kajian lingkungan strategis dalam penyusunan dan evaluasi rencana tata ruang dan bagaimanakan optimalisasi kajian lingkungan startegis dalam rencana tata ruang dalam mewujudkan pembangunan berkelanjutan.

Tujuan Penelitian adalah untuk mengetahui, mengidentifikasi serta menganalisis fungsi dan kedudukan kajian lingkungan strategis dalam penyusunan dan evaluasi rencana tata ruang dalam upaya mewujudkan pembangunan berkelanjutandi Indonesia.

Gita Arwana Cakti (ed), Dokumen KLHS Dikebut, Kalimantan Pos, dalam http://kalimantan.bisnis.com/ $\mathrm{read} / 20170313 / 436 / 636417 /$ dokumen-klhs-dikebut-

${ }^{8}$ Kementerian Perintahkan KLHS Masuk Raperda Reklamasi, Koran Tempo, dalam https://koran.tempo.co/konten/2017/07/11/418980/Kementerian-Perintahkan-KLHS-Masuk-Raperda-Reklamasi, 11 Juni 2017

${ }^{9}$ Dengan perubahan nomenklatur Kementerian, setelah tahun 2014, kementerian yang menyelenggarakan urusan pemerintahan bidang penataan ruang berada pada Kementerian Agraria dan Tata Ruang/ BPN.

${ }^{10}$ Maret Priyanta, Makalah Aspek Pengaturan KLHS Bidang Penataan Ruang, Direktorat Jenderal Penataan Ruang, Kementerian Pekerjaan Umum, 2014. 
Penelitian ini menggunakan pendekatan yuridis normatif, pendekatan melalui peraturan perundang-undangan, konseptual dan pendekatan analitis. Penelitian hukum normative mencakup penelitian terhadap asas-asas hukum, penelitian terhadap harmonsasi vertical dan horizontal dan sistematika hukum. Penelitian ini merupakan penelitian deskriptif, yaitu penelitian yang bersifat menemukan data dan informasi, dimana terhadap data dan informasi yang ditemukan dilakukan analisis kualitatif dengan menggunakan metode penafsiran gramatikal, dan penafsiran sistematik.

\section{PEMBAHASAN}

Konstitusi 1945 mengamatkan Negara untuk melindungi segenap bangsa dan seluruh tumpah daran melalui berbagai upaya. Perlindungan fungsi lingkungan menjadi aspek yang penting mengingat makin menurunnya kualitas lingkungan. Hukum pada dasarnya bertujuan untuk mewujudkan ketertiban, kepastian dan keadilan dalam masyarakat, ${ }^{11}$ sejalan dengan hal tersebut, berdasarkan Konstitusi 1945, Indonesia adalah Negara hukum.

Pembangunan nasional sebagai sebuah upaya pemerintah dalam rangka mewujudkan kesejahteraan masyarakat memerlukan berbagai sumber daya. Dalam pelaksanaannya pertimbangan mengenai lingkungan menjadi hal yang utama dalam rangka mewujudkan pembangunan berkelanjutan. Pelestarian fungsi lingkungan juga diupayakan dalam rangka mendukung kehidupan manusia dan makhluk hidup lainnya serta mengantisipasi isu lingkungan global. ${ }^{12}$

Munadjat Danusaputro menyatakan bahwa hukum dalam arti peraturan perundangundangan di bidang lingkungan harus bersumber pada ekologi. Hal tersebut mendasari pengertian ekosistem dalam peraturan perundang-undangan di Indonesia, dimana dinyatakan bahwa ekosistem merupakan tatanan unsur lingkungan hidup yang merupakan kesatuan utuh-menyeluruh dan saling mempengaruhi dalam membentuk keseimbangan, stabilitas, dan produktivitas lingkungan hidup. ${ }^{13}$ Dalam ekosistem, kehidupan akan berlangsung berbagai fenomena kehidupan menurut prinsip, tatanan dan hukum alam atau ekologi seperti keseimbangan (homeostasis), kelentingan (resilience atau kelenturan), kompetisi, toleransi, adaptasi, suskesi, evolusi, mutasi, hukum minimum, hukum entropi dan sebagainya. ${ }^{14}$

Dalam lingkungan, perkembangan kebudayaan manusia mempengaruhi perkembangan lingkungan. Hal tersebut menunjukan bahwa kebutuhan manusia tidak hanya sekedar kebutuhan hidup secara hayati, namun secara tidak langsung manusia mengupayakan peningkatan kualitas hidupnya dengan melakukan perubahan, pengelolaan dan pemanfaatan terhadap lingkungan. ${ }^{15}$ Interaksi manusia terhadap lingkungan alami telah mengubah lingkungan alami menjadi lingkungan buatan (manmade environment), hal ini secara tidak langsung mempengaruhi keseimbangan dan kelentingan lingkungan dalam mendukung kehidupan manusia dan makhluk hidup lainnya.

\footnotetext{
${ }^{11}$ Mochtar Kusumaatmadja, 1972, Fungsi Dan Perkembangan Hukum dalam Pembangunan Nasional, Bina Cipta, hlm 5 .

${ }^{12}$ Lihat Pasal 3 Undang-Undang Nomor 32 Tahun 2009 tentang Perlindungan dan Pengelolaan Lingkungan Hidup.

${ }^{13}$ Lihat Undang-Undang Nomor 32 Tahun 2009 tentang Perlindungan dan Pengelolaan Lingkungan Hidup.

${ }^{14}$ Otto Soemarwoto, 2004, Atur Diri Sendiri: Paradigma Baru Pengelolaan Lingkungan Hidup, Gadjah Mada University Press, Cetakan ketiga, hlm. 60

${ }^{15}$ Moh. Soerjani, Rofiq Ahmad, Rozy Munir (Ed), 1987, Lingkungan: Sumberdaya Alam dan Kependudukan dalam pembangunan, UI Press, hlm 6.
} 
Pada prinsipnya susunan komponen dan fungsinya harus dilihat secara utuh. Pandangan dalam mendekati dan memahami permasalahan lingkungan antara lain: Kesatu, pandangan holisme sebagai pandangan yang utuh terhadap lingkungan, mengingat bahwa semua komponen kehidupan saling berinteraksi satu dengan yang lain, saling mempengaruhi dan saling terkait, Daud Silalahi menyatakannya sebagai pendekatan ekosistem atau pendekatan holistik ${ }^{16}$, Kedua, pandangan hukum (aturan/ ketentuan) mininum, bahwa nilai, hasil atau kualitas suatu sistem ditentukan oleh faktor pendukungnya dalam keadaan minimum, sehingga hukum (aturan/ketentuan) minimum dapat ditentukan permasalahan lingkungan yang terpenting untuk menentukan hal yang menjadi prioritasnya, Ketiga, etika lingkungan yang merupakan prinsip moral lingkungan sebagai petunjuk atau arah perilaku praktis manusia dalam mengusahakan terwujudnya moral lingkungan. Permasalahan lingkungan termasuk perubahan iklim memuat moral dalam kaitan dengan kehidupan manusia. ${ }^{17}$ Dalam etika lingkungan kita tidak saja mengimbangi hak dengan kewajiban terhadap lingkungan, tetapi etika lingkungan juga membatasi tingkah laku untuk mengendalikan berbagai kegiatan agar tetap berada dalam batas kelentingan lingkungan. ${ }^{18}$

Dalam perkembangan pengaturan penataan ruang di Indonesia, pada tahun 2007 ditetapkanlah undang-undang penataan ruang yang menggantikan pengaturan pada tahun 1992. Adapun beberapa pertimbangan dibutuhkannya perubahan pengaturan, antara lain: Kesatu, situasinasional dan internasional yang menuntut penegakan prinsipketerpaduan, keberlanjutan, demokrasi, dan keadilan dalamrangka penyelenggaraan penataan ruang yang baik. Kedua, pelaksanaan kebijakan otonomi daerah yang memberikanwewenang yang semakin besar kepada pemerintah daerahdalam penyelenggaraan penataan ruang sehingga pelaksanaankewenangan tersebut perlu diatur demi menjaga keserasiandan keterpaduan antardaerah, serta tidak menimbulkankesenjangan antardaerah. Ketiga, kesadaran dan pemahamanmasyarakat yang semakin tinggi terhadap penataan ruangyang memerlukan pengaturan, pembinaan, pelaksanaan, danpengawasan penataan ruang agar sesuai denganperkembangan yang terjadi di masyarakat.

Ruang harus dipahami sebagai satu kesatuan. Amiruddin A. Dajaan menyatakan bahwa ruang daratan, ruang lautan dan ruang udara merupakan satu kesatuan ruang yang tidak dapat dipisah-pisahkan. Ruang mempunyai potensi yang dapat dimanfaatkan sesuai dengan tingkat intensitas yang berbeda untuk kehidupan manusia dan makhluk hidup lainnya. ${ }^{19}$ Pengembangan tata ruang yang dinamis serta tetap memelihara kelestarian kemampuan lingkungan, maka pengelolaan sumberdaya alam yang beraneka ragam di daratan, di lautan dan di udara dapat dilakukan secara terkoordinasi dan terpadu dengan sumberdaya manusia dan sumberdaya buatan dalam pola pembangunan yang berkelanjutan. ${ }^{20}$

RTR sebagai sebuah produk pelaksanaan penataan ruang menjadi salah satu dasar dalam pemanfaatan ruang. Pemahaman ruang sebagai wadah yang didalamnya meliputi ruang darat, ruang laut, dan ruang udara, termasuk ruang di dalam bumi sebagai satu kesatuan wilayah, tempat manusia dan makhluk lain hidup, melakukan kegiatan, dan

\footnotetext{
${ }^{16}$ M. Daud Silalahi, 2001, Hukum Lingkungan Dalam Sistem Penegakan Hukum Lingkungan Indonesia, Alumni, Bandung, hlm.2.

${ }^{17}$ Lihat Heap, Brian and Flavio Comim Von Hügel Institute, 2009, St Edmund's College, Cambridge, UK, Climate Change and Well-Being, International Journal of Public Th eology 3, hlm.62.

${ }^{18}$ ibid, hlm.15-16

${ }_{19}$ Amiruddin Ahmad Dajaan Imami, April 1995, Perkembangan Pemikiran Pengaturan dalam penataan Ruang Dewasa Ini, Pro Justitia Tahun XIII Nomer, hlm.59.

${ }^{20}$ Ibid.
} 
memelihara kelangsungan hidupnya menjadi perhatian dimana pengaturan rencana tata ruang harus ditujukan untuk mempertahankan wadah dalam rangka perlindungan fungsi lingkungan.

Penyusunan penataan ruang wilayah nasional, penataan ruangwilayah provinsi, dan penataan ruang wilayahkabupaten/kota dilakukan secara berjenjang dan komplementer. Berjenjang dimaknai bahwa penetapannya memperhatikan ketentuan tata urutan peraturan perundang-undangan. Selanjutnya komplementer dimaknai bahwa penataan ruang wilayah nasional, penataan ruang wilayah provinsi, dan penataan ruang wilayah kabupaten/kota saling melengkapi satu sama lain, bersinergi, dan tidak terjadi tumpang tindih kewenangan dalam penyelenggaraannya.

\section{Gambar 1}

Hubungan Dokumen Rencana Tata Ruang Nasional, Provinsi dan Kabupaten/Kota

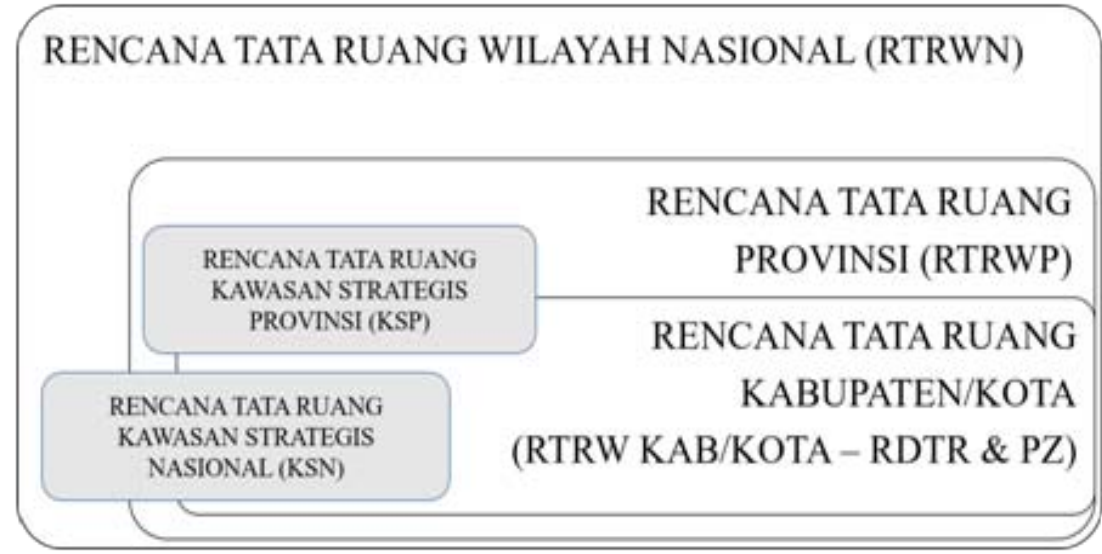

Sumber:Undang-Undang Nomor 26 Tahun 2007 tentang Penataan Ruang

Berkenaan dengan KLHS, pemerintah telah menetapkan Peraturan Menteri Negara Lingkungan Hidup Republik Indonesia Nomor 09 Tahun 2011 Tentang Pedoman Umum Kajian Lingkungan Hidup Strategis. Beberapa hal yang menjadi materi muatan peraturan menteri tersebut antara lain:

Kesatu,KLHS ditujukan untuk menjamin pengarusutamaan pembangunan berkelanjutan dalam pembangunan. Tiga nilai penting dalam penyelenggaraan KLHS yang mencerminkan penerapan prinsip pembangunan berkelanjutan adalah (1) keterkaitan (interdependency), (2) keseimbangan (equilibrium) dan (3) keadilan (justice);

Kedua, Untuk penyusunan dan evaluasi kebijakan, rencana, dan/atau program yang terkait penataan ruang, kewajiban penyelenggaraan KLHS melekat pada Peraturan Pemerintah (PP) Nomor 15 tahun 2010 tentang Penyelenggaraan Penataan Ruang. Dalam PP ini telah diatur bahwa penyusunan rencana tata ruang harus memperhatikan daya dukung, daya tampung dan daya lenting lingkungan hidup melalui Kajian Lingkungan Hidup Strategis. Hal ini sesuai dengan UU PPLH yang mewajibkan penyelenggaraan KLHS dalam penyusunan dan evaluasi atau peninjauan kembali rencana tata ruang dengan memperhatikan daya dukung, daya tampung dan daya lenting lingkungan hidup;

Ketiga, Dalam penyusunan dan evaluasi RPJP dan RPJM, baik untuk tingkat nasional, provinsi, dan kabupaten/kota, wajib dilaksanakan KLHS. Pengintegrasian KLHS secara teknis untuk RPJP/RPJM pada tingkat nasional akan ditentukan lebih lanjut oleh Bappenas, dan pada tingkat provinsi dan kabupaten/kota oleh Kementerian Dalam Negeri. 
Keempat, Identifikasi dan pelibatan masyarakat dan pemangku kepentingan dapat dilakukan sesuai proses dan prosedur penyusunan dan evaluasi masing-masing kebijakan, rencana, dan/atau program, misalnya untuk penyusunan rencana tata ruang, hal ini mengacu pada Peraturan Pemerintah Nomor 68 Tahun 2010 tentang Bentuk dan Tata Cara Peran Masyarakat dalam Penataan Ruang.

Kelima, Peraturan ini mendeskripsikan keterkaitaan dengan KLHS yaitu bahwa dalam penetapan struktur ruang, misalnya penetapan susunan pusat permukiman, harus ditetapkan dengan mempertimbangkan akibatnya pada perubahan daya dukung lingkungan hidup (seperti penurunan ketersediaan sumber daya air) atau berakibat pada penurunan jasa ekosistem (seperti penurunan luas kawasan hutan lindung). Lebih lanjut dalam penetapan kawasan budidaya tertentu harus memperhatikan berakibat pada perubahan daya dukung lingkungan hidup (seperti kapasitas pasokan pangan); berakibat pada jasa ekosistem (seperti berkurangnya kawasan resapan air) atau berakibat pada dampak lingkungan (seperti kebisingan dan polusi udara).

Berdasarkan pengaturan tersebut, sudah terdapat keterkaitan langsung antara dokumen KLHS dengan penataan ruang serta dalam penyusunan dan evaluasi rencana tata ruang, dokumen KLHS telah menjadi salah satu persyaratan formil selain naskah akademik dalam penyusunan peraturan perundang-undangan. ${ }^{21}$

Pada dasarnya KLHS bertujuan untuk menjamin pembangunan berkelanjutan menjadi pertimbangan utama dalam kegiatan pemanfaatan lingkungan termasuk sumberdaya di dalamnya. Perwujudan konsep berkelanjutan di Indonesia saat ini diintegrasikan dan didasarkan pada KLHS yang memuat berbagai ketentuan dan arahan bagaimana mewujudkan pembangunan berkelanjutan berdasarkan UUPPLH menjadi dasar dalam penyusunan dan evaluasi RTR dan rencana pembangunan. Secara mendasar KLHS mengkaji daya tampung, daya dukung dan daya lenting lingkungan yang dengan kata lain mengidentifikasi kemampuan lingkungan pada kawasan yang direncanakan untuk dimanfaatkan termasuk kawasan yang harus dipertahankan fungsinya. Sehingga KLHS penting disusun sebagai dasar perencanaan tata ruang sebagai wadah dan perencanaan pembangunan.

Dalam upaya mengurangi dampak negatif dari pembangunan, konsep Pembangunan berkelanjutan disepakati dalam Konferensi Rio de Janeiro Tahun 1992. Pembangunan berkelanjutan didefinisikan oleh Komisi Brundland yaitu World Commision on Environment and Development (WCED) sebagai pembangunan yang memenuhi kebutuhan sekarang tanpa mengurangi kemampuan generasi-generasi mendatang memenuhi kebutuhannya sendiri, sebagaimana tercantum dalam laporan Komisi Brundland "Our Common Future" pada tahun 1987. WCED mendekati masalah lingkungan dan pembangunan dari enam sudut pandang antara lain keterkaitan (interdependency), berkelanjutan (sustainability), pemerataan (equity), sekuriti dan resiko lingkungan, pendidikan dan komunikasi, dan kerjasama internasional.

Proses pembangunan berkelanjutan bertumpu pada kondisi sumberdaya alam, kualitas lingkungan dan faktor kependudukan. Mengingat ketiga faktor diatas maka upaya pembangunan berwawasan lingkungan perlu memelihara keutuhan fungsi tatanan lingkungan agar lingkungan dapat secara berlanjut menopang proses pembangunan

${ }^{21}$ Lihat DPR Minta Kepala Daerah Perhatikan Tata Ruang, dalam http://www.penataanruang.com/tata-ruang/ category/bangka \% 20belitung, Lihat juga Pembahasan RTRWditeruskan,dalam:http://www.suaramerdeka.com/v1/ index.php/read/cetak/2011/03/17/140235/Pembahasan-RTRW-Diteruskan. 
secara terus menerus dari generasi ke generasi untuk meningkatkan kualitas manusia Indonesia.

Adapun prinsip utama dari pembangunan berkelanjutan dan berwawasan lingkungan antara lain :

1. Keadilan antar generasi yang mengandung makna bahwa seluruh kegiatan atau usaha manusia, tidak hanya untuk kepentingan generasi sekarang, tetapi juga harus mempertimbangkanpemenuhankebutuhandankepentingangenerasiyangakandatang;

2. Keadilan dalam satu generasi yang menekankan pada pentingnya keadilan dalam satu generasi guna memenuhi kebutuhan dasar manusia serta mahkluk hidup lainnya;

3. Prinsip pencegahan dini yang mengandung makna bahwa apabila ada ancaman atau dapat diduga akan menimbulkan pencemaran atau kerusakan lingkungan, ketiadaan pembuktian ilmiah yang konklusif dan pasti, tidak dapat dijadikan untuk menundanunda upaya npencegahan pencemaran atau kerusakan lingkungan. perlindungan keanekaragaman hayati; dan

4. Internalisasibiayalingkunganhidupdanmekanismeinsentif. (sosialCostterkaitdengan tanggung jawab).

KLHS harus menjadi dasar dalam penyusunan dan evaluasi ${ }^{22}$ rencana tata ruang. Pada prakteknya KLHS disusun secara kondisional sesuai dengan kebutuhan, sehingga KLHS disusun saat tertentu dan sesuai kebutuhan tertentu. Permasalahan lainnya, KLHS sebagai kajian yang bersifat desktiptif tidak memberikan hal-hal apa saja yang tegas atau cara integrasi terhadap terhadap materi muatan rencana tata ruang secara pasti. Pada dasarnya rencana tata ruang disusun dengan tetap mengakomodasi kepentingan dan berbagai tujuan undang-undang sector lainnya, sehingga sangat penting penguatan KLHS dalam menentukan fungsi kawasan yang akan menjadi dasar kegiatan pembangunan. Sehingga penyusunan rencana tata ruang dengan pendekatan keterpaduan menjadi prioritas utama dalam pembaruan aturan-aturan di bidang lingkungan. Hal yang mendasar adalah harmonisasi terminologi antara pengaturan bidang lingkungan dengan penataan ruang.

Beberapa kaitan antara KLHS dan Rencana Tata Ruang antara lain, Kesatu, Rencana tata ruang sebagai wadah harus disusun dengan mempertimbangkan KLHS yang memuat daya tampung, daya dukung dan daya lenting lingkungan. Adapun integrasi KLHS pada penyusunan dan evaluasi rencana tata ruang secara tidak langsung akan mendukung dan mendorong pembangunan berkelanjutan. Kedua, Rencana pembangunan nasional dan daerah menjadi dasar untuk setiap kebijakan dalam wujud visi misi, program, dan kegiatan dalam pembangunan.

\section{Gambar 2}

Pergeseran Kedudukan Tata Ruang dalam

Sistem Hukum Lingkungan Indonesia Pasca tahun 1992

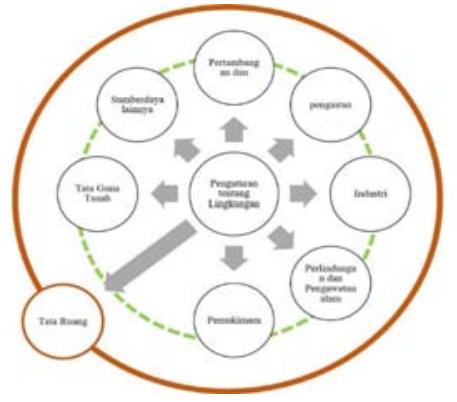

\footnotetext{
${ }^{22}$ Evaluasi Rencana Tata Ruang dilakukan melalui Peninjauan Kembali didahului melalui penetapan.
} 
Berkenaan dengan undang-undang yang terkait dengan perlindungan dan pengelolaan lingkungan, keengganan untuk mengharmoniskan tujuan bersama muncul dalam berbagai aturan yang pada prinsipnya memiliki keterkaitan. Apabila didudukkan kaitannya aturan yang ada, sekurang-kurangnya terdapat 3 (tiga) undang-undang di Indonesia saat ini yaitu Kesatu, undang-undang tentang Penataan Ruang, Kedua, undangundang tentang Perlindungan dan pengelolaan Lingkungan hidup, dan Ketiga, undangundang tentang sistem perencanaan pembangunan nasional. Dalam pandangan ini, pengaturan hutan dan sumberdaya lainnya ditempatkan sebagai bagian dari lingkungan yang seharusnya sinegis dengan pengaturan lingkungan.

Keterkaitan ini pada prakteknya belum sepenuhnya dipahami oleh berbagai pihak yang berkepentingan. Bahwa KLHS sebagai sebuah kajian, pada dasarnya memberikan gambaran mengenai daya dukung, daya tampung dan daya lenting lingkungan dalam arti kemampuan sebuah kawasan dan sumberdaya. KLHS ini harus dijadikan dasar untuk menyusun sebuah rencana dan kegiatan pembangunan apa yang masih dapat dilakukan pada sebuah kawasan, atau sumberdaya apa yang masih dapat dimanfaatkan. Hal tersebut seharusnya dijadikan dasar untuk menetapkan fungsi dan peruntukan suatu kawasan serta kegiatan pembangunan apa yang masih memungkinkan untuk dapat dilaksanakan.

Dalam penyusunan dan evaluasi rencana tata ruang, KLHS selalu dimintakan sebagai salah satu persyaratan untuk membahas rencana yang dibuat, namun kajian yang dibuat masih disusun secara umum sehingga hal-hal apa saja harus diakomodasi, serta bagaimana cara mengkaitkan KLHS dengan rencana tata ruang belum secara tegas diatur. Hal ini menyebabkan KLHS dibuat khusus sebagai salah satu proses serta hanya ditempatkan sebagai persyaratan formil dalam penyusunan atau evaluasi rencana tata ruang. Dalam penyusunan rencana pembangunan, KLHS justru tidak pernah dibuat dalam proses penyusunan rencana pembangunan, dan dalam praktek rencana pembangunan hanya didasarkan pada visi misi yang akan dijalankan oleh calon presiden dan kepala daerah.

Penataan ruang mengamanatkan agar pengelolaan sumber daya alam yang beraneka ragam di daratan, di lautan, dan di udara, perlu dilakukan secara terkoordinasi dan terpadu dengan sumber daya manusia dan sumber daya buatan. Dalam pola pembangunan yang berkelanjutan tata ruang dikembangkan dalam satu kesatuan tata lingkungan yang dinamis serta tetap memelihara kelestarian kemampuan lingkungan hidup sesuai dengan pembangunan berwawasan lingkungan, yang berlandaskan Wawasan Nusantara dan Ketahanan Nasional

Rencana tata ruang nasional menetapkan bahwa rencana pola ruang nasional, meliputi Kawasan lindung nasional dan kawasan budi daya yang memiliki nilai strategis nasional. Pengaturan ini mengandung makna bahwa terdapat kawasan lindung dan budidaya yang kawasannya berada dalam wilayah provinsi, kabupaten dan kota yang memiliki nilai strategis dan langsung serta diprioritaskan oleh negara. Hal ini juga mengandung makna bahwa provinsi dan kabupaten/kota dapat juga menetapkan kawasan lindung dan kawasan budidaya diluar kawasan yang ditetapkan oleh pusat dalam rencana tata ruang wilayahnya

Kawasanlindung nasional ditetapkan sebagaikawasanyangmemberikan perlindungan terhadap kawasan bawahannya, kawasan perlindungan setempat, kawasan suaka alam, pelestarian alam, dan cagar budaya, kawasan rawan bencana alam, kawasan lindung geologi; dan kawasan lindung lainnya. Pada bidang kehutanan rencana pola ruang nasional telah menetapkan kawasan hutan yang mempunyai fungsi sebagai sistem 
penyangga kehidupan sebagai kawasan lindung. Idealnya kedepan seluruh terminologi terkait dalam pengaturan penataan ruang dan kehutanan harmonis dalam rencana tata ruang nasional. Khusus mengenai penetapan kawasan lindung nasional, KLHS, penataan ruang dan kehutanan diharmoniskan

Pada dasarnya, KLHS menjadi dasar untuk menetapkan kawasan lindung dengan pendekatan dan mengkaji sejauh mana kondisi daya tampung, daya dukung dan daya lenting pada kawasan tersebut, serta dapat merekomendasi hal-hal yang harus diperhatikan sebagai dasar rencana tata ruang merencanakan kawasan tersebut kedepan. Kriteria dalam RTRWN dalam mengidentifikasi suatu kawasan menjadi penting sebagai dasar nilai strategis dan prioritas penetapkan kawasan. Berkenaan dengan rencana pola ruang untuk kawasan yang berfungsi budi daya, pada dasarnya menetapkan peruntukan kawasan yang berfungsi sebagai budi daya antara lain: kawasan peruntukan hutan produksi, kawasan peruntukan hutan rakyat, kawasan peruntukan pertanian, kawasan peruntukan perikanan, kawasan peruntukan pertambangan, kawasan peruntukan industri, kawasan peruntukan pariwisata, kawasan peruntukan permukiman; dan/atau kawasan peruntukan lainnya.

Dalam pandangan perlindungan fungsi lingkungan, pengaturan tentang lingkungan dan tata ruang secara terpadu berusaha mengendalikan pembangunan khususnya yang memanfaatkan sumber daya alam menjadi lebih terkendali. Sehingga pada tataran konsep awal pengaturan kegiatan pembangunan merupakan unsur yang secara langsung maupun tidak langsung bersentuhan dengan pengaturan lingkungan dan tata ruang sebagai pengendali untuk tetap menjamin keberlanjutan sumber-sumber daya untuk kepentingan generasi yang akan datang.

Berdasarkan pertimbangan-pertimbangan tersebut, kedudukan penataan ruang harus berdasarkan pada pemikiran, Kesatu, bahwa berbicara mengenai hukum lingkungan dan penataan ruang, optimaliasi tidak dapat dilepaskan dari perkembangan ilmu pengetahuan yang melandasi pembentukan pengaturan bidang lingkungan dan penataan ruang, Kedua, bahwa lingkungan merupakan satu kesatuan sistem yang terdiri dari unsur-unsurnya, sehingga pengaturannya harus mengedepankan pendekatan utuh menyeluruh, Ketiga, bahwa tata ruang, sebagai sebuah wadah memiliki fungsi utama unttuk menjamin keterpaduan antar kepentingan dan antarsektor untuk samasama mewujudkan tujuan dari pengelolaan lingkungan, sehingga dengan pandangan kedepan baik lingkungan dan penataan ruang, mengedepkan asas kehati-hatian dalam pandangan penaatan (preventif) untuk mencegah dampak negatif terhadap lingkungan yang disebabkan kegiatan pemanfaatan ruang.

\section{SIMPULAN}

Berdasarkan hasil pembahasan, KLHS merupakan instrument penting dalam rangka pencegahan dampak negatif pemanfaatan ruang terhadap lingkungan,,KLHS yang ditujukan untuk menjamin prinsip pembangunan berkelanjutan diterapkan menyebabkan fungsi dan kedudukan KLHS dalam penyusunanan dan evaluasi rencana tata ruang menjadi hal yang utama mengingat rencana tata ruang merupakan dasar bagi seluruh kegiatan pemanfaatan ruang saat ini. Integrasi KLHS dalam rencana tata ruang harus dapat memberikan kepastian hukum dapalam materi muatan RTR dalam merencanakan kawasan yang memiliki fungsi lindung dan fungsi budidaya mengingat rencana tata ruang memuat kebijakan pemerintah hasil keterpaduan dan keharmonisan antar sektor, antar wilayah dan antar kewenangan, sehingga justifikasi ilmiah KLHS 
berupa kejelasan dapat memberikan arahan serta kepastian terhadap kawasan-kawasan yang direncanakan untuk terus dipertahankan maupun diubah fungsinya dengan memperhatikan daya tampung, daya dukung dan daya lenting, serta tidak semata-mata memperhatikan kepentingan yang tidak berorientasi pada lingkungan. Optimalisasi KLHS dalam penyusunan dan evaluasi rencata tata ruang harus diwujudkan melalui peningkatan kualitas dokumen KLHS yang sesuai tepat guna serta dengan kebutuhan pengaturan dalam materi muatan rencana tata ruang, serta dapat memberikan kepastian kepada pemerintah untuk melakukan perubahan terhadap kawasan-kawasan yang tidak aman, nyaman, produktif dan berkelanjutan sebagaimana tujuan pengaturan UUPR.

\section{DAFTAR PUSTAKA}

\section{Buku}

Amiruddin Ahmad Dajaan Imami, April 1995. Perkembangan Pemikiran Pengaturan dalam penataan Ruang Dewasa Ini, Pro Justitia Tahun XIII Nomer. 2.

Heap, Brian and Flavio Comim, 2009. Von Hügel Institute, St Edmund's College, Cambridge, UK, Climate Change and Well-Being, International Journal of Public The eology 3.

Mochtar Kusumaatmadja, 1972. Fungsi Dan Perkembangan Hukum dalam Pembangunan NasionalBina Cipta.

Moh. Soerjani, Rofiq Ahmad, Rozy Munir (Ed), 1987. Lingkungan: Sumberdaya Alam dan Kependudukan dalam pembangunan, UI Press.

Otto Soemarwoto, 2004. Atur Diri Sendiri: Paradigma Baru Pengelolaan Lingkungan Hidup,Cetakan ketiga, Gadjah Mada University Press,

Silalahi M. Daud, 2001. Hukum Lingkungan Dalam Sistem Penegakan Hukum Lingkungan Indonesia, Alumni, Bandung.

\section{Peraturan Perundang-Undangan}

Undang-Undang Nomor 26 Tahun 2007 tentang Penataan Ruang

Undang-Undang Nomor 32 Tahun 2009 tentang Perlindungan dan Pengelolaan Lingkungan Hidup.

Peraturan Menteri Pekerjaan Umum Nomor : 16/PRT/M/2009 Tentang Pedoman Penyusunan Rencana Tata Ruang Wilayah Kabupaten

\section{Sumber Lain}

Kementerian Perintahkan KLHS Masuk Raperda Reklamasi, Koran Tempo, dalam https://koran.tempo.co/konten/2017/07/11/418980/KementerianPerintahkan-KLHS-Masuk-Raperda-Reklamasi, 11 Juni 2017.

DPR Minta Kepala Daerah Perhatikan Tata Ruang, dalam http://www.penataanruang. com/tata-ruang/category/bangka \%20belitung, Lihat juga Pembahasan RTRW diteruskan,dalam:http://www.suaramerdeka.com/v1/index.php/read/ cetak/2011/03/17/140235/Pembahasan-RTRW-Diteruskan.

Gita Arwana Cakti (ed), Dokumen KLHS Dikebut, Kalimantan Pos, dalam http:// kalimantan.bisnis.com/read/20170313/436/636417/dokumen-klhs-dikebut-

Maret Priyanta, Makalah Aspek Pengaturan KLHS Bidang Penataan Ruang, Direktorat 
Jenderal Penataan Ruang, Kementerian Pekerjaan Umum, 2014.

----------, Pembaruan dan Harmonisasi Peraturan Perundang-undangan Bidang Lingkungan dan Penataan Ruang Menuju Pembangunan Berkelanjutan, Hassanudin Law review (HARLEV), Volume I Issue 3 Desember 2015. 